\title{
Analisis Keberlanjutan Integrasi Sapi Sawit Di Kecamatan Bahar Utara, Kabupaten Muaro Jambi
}

\author{
Analysis of the Sustainability of Palm oil and Cattle Integration Farming in \\ North Bahar District, Muaro Jambi Regency \\ Hutwan Syarifuddin*, J Jalius dan Syafril Hadi \\ Fakultas Peternakan Universitas Jambi Jl. Raya Jambi -Ma Bulian KM 15 \\ Mandalo Indah 36361 korespondensi:08127807950 email:hutwan@yahoo.co.id
}

\begin{abstract}
Intisari
Penelitian telah dilakukan di Kecamatan Bahar Utara, Kabupaten Muaro Jambi. Tujuan penelitian adalah; (1) mengidentifikasi faktor-faktor penentu keberadaan integrasi sapi - sawit untuk masa depan, (2) merumuskan kebijakan integrasi sapisawit berkelanjutan di Kecamatan Bahar Utara. Hasil penelitian menunjukkan bahwa dimensi ekologis adalah 55,12\%. dan faktor sensitif untuk pemanfaatan hijauan di bawah tanaman sawit sebagai pakan ternak, dimensi ekonomi $79,60 \%$ untuk faktor kemitraan perusahaan dengan petani dan dimensi sosial $52,17 \%$ untuk faktor persepsi / peran masyarakat dalam pertanian CLS (Crop livestock system). Hal ini mengindikasikan bahwa cukup untuk sistem integrasi sapi-sawit yang berkelanjutan.
\end{abstract}

Kata kunci: Integrasi, Sapi, Sawit, Keberlanjutan.

\begin{abstract}
Field research was conducted in North Bahar Subdistrict, Muaro Jambi Regency. The research objectives (1) to identify the determinants of the existence of palm oil cattle integration for the future, (2) to formulate a sustainable palm oil-cattle integration policy in the North Bahar Subdistrict. The results showed that the ecological dimensions was $55.12 \%$ and sensitive factors forage utilization under palm oil plants for cattle feed, economic dimensions $79.60 \%$ sensitive factors company partnership with farmers and social dimensions $52.17 \%$ sensitive factors Perception / role of the community in CLS farming. This is indicated to be sufficient to sustainable the integration system for palm oil- cattle.
\end{abstract}

Key words: Integration, Cattle, Palm Oil, Sustainability.

\section{Pendahuluan}

Kabupaten Muaro Jambi dengan luas wilayah $5.264 \mathrm{~km}^{2}$ terletak di antara $10^{\circ} 30^{\prime} 0^{\prime \prime}-2^{\circ} 00^{\prime} 0^{\prime \prime}$ LS dan di antara 103030'0"- 104\% 0'0"BT. Di Kabupaten Muaro Jambi terdapat 11 Kecamatan. Kecamatan Bahar Utara dengan topografi dataran, memiliki luas \pm 15.937 Ha merupakan salah satu kecamatan yang memiliki kebun sawit dan integrasi ternak sapi. Ternak sapi yang dipelihara peternak merupakan pemasok komoditi daging bagi Kota Jambi (BPS Muaro Jambi, 2017). Komoditas tanaman sawit Bahar Utara sebanyak 377.045 pohon dan populasi sapi sebanyak 1.749 ekor (Kabupaten Muaro Jambi Dalam Angka, 2017). 
Pola integrasi sawit-sapi sudah dicanangkan untuk pemanfaatan lahan dan pengembangan ternak sapi pada wilayah yang memiliki perkebunan sawit dalam rangka swasembada daging dan untuk memenuhi kebutuhan protein hewani (Permentan no 105 tahun 2014) tentang integrasi perkebunan kelapa sawit dengan budidaya sapi potong.

Potensi yang dimiliki Kecamatan Bahar Utara sangat besar untuk integrasi sawit-sapi. Pola budidaya ternak yang dilepas di perkebunan sawit akan mengurangi penggunaan tenaga kerja dalam budidaya dan ternak sapi dapat bergerak secara bebas dalam mencari pakan, tetapi saat ini kondisi ternak sapi yang ada di Kecamatan Bahar Utara mengalami penurunan populasi yang sangat signifikan, hal ini disebabkan karena adanya penyakit ternak (penyakit jemrana). Populasi sapi saat ini tinggal sekitar 300 ekor dari populasi 1749 ekor.

Peluang integrasi sawit-sapi sangat perlu untuk dilakukan dengan cara menyusun strategi kebijakan untuk mengurangi ancaman dan kelemahan yang masih ada dalam pengembangan ternak sapi di lahan perkebunan kelapa sawit (Diwyanto, et al. 2004). Strategi yang dilakukan dengan mengukur indeks keberlanjutan usaha sapi-sawit berdasarkan kondisi yang ada saat ini. Menurut Syarifuddin (2010) Indeks keberlanjutan pola CLS di Sungai Bahar sebesar 52,92 $\%$ dalam kategori cukup berlanjut.
Sistem integrasi sawit-sapi merupakan alternatif terbaik untuk mencapai target swasembaga pangan. Sumber pakan sapi sekitar $30-65 \%$ dari pelepah sawit, 10-70\% bungkil inti sawit, dan 20-35\% bahan non sawit (Husnain dan Dedi, 2015).

Berdasarkan kondisi saat ini keberadaan ternak sapi yang diintegrasikan dengan perkebunan kelapa sawit masih belum mendapat perhatian yang optimal dari pemerintah sehingga perlu dilakukan penelitian mengenai strategi kebijakan integrasi sawitsapi.

\section{Metode Penelitian}

Penelitian dilakukan di Kecamatan Bahar Utara Kabupaten Muaro Jambi yang terdapat integrasi sawit-sapi. Penelitian pada bulan April sampai September 2018 dan pengolahan data dilakukan di Fakultas Peternakan Universitas Jambi

Jenis penelitian ini adalah penelitian deskriptif dan inferensial yaitu penelitian yang menggambarkan dan menguraikan kenyataan-kenyataan kehidupan petani pada sistem integrasi sapi sawit Di Kecamatan Bahar Utara.

Jenis data yang digunakan adalah data kualitatif dan kuantitatif ((Kavanagh dan Pitcher, 2004). Data yang dikumpulkan dalam penelitian ini terdiri dari data primer dan data sekunder. Data primer diperoleh langsung dari nara sumber melalui Focus Group Discussion (FGD). Untuk mendapatkan dan menggali informasi dan pengetahuan dari 
para pakar (expert survey) dilakukan dengan teknik wawancara mendalam (in-depth interview). Penentuan banyaknya responden (pakar) harus memenuhi persyaratan sesuai dengan keilmuan dan kewenangannya (Marimin, 2002).

Adapun data sekunder, berupa data dan informasi yang berkaitan dengan ketiga dimensi keberlanjutan, diperoleh dari hasil studi dokumentasi dan studi terhadap hasil-hasil penelitian, literatur terkait, data monografi lokasi penelitian.

Analisis data integrasi sapi sawit berkelanjutan menggunakan analisis Rap-CP (Rapid Appraisal of the Status for Cattle-Palm Oil) (Kavanagh, 2001; Pitcher \& Preikshot, 2001; Alder et al., 2000; Cisse et al., 2014), terdiri dari analisis Multi-Dimensional Scaling (MDS), analisis Monte Carlo dan analisis Leverage.

Tahapan analisis keberlanjutan dengan metode Rap-CP (Syarifuddin. (2010) yaitu: penentuan atribut/ kriteria; (2) penilaian atribut/kriteria; (3) penilaian indeks dan status keberlanjutan melalui analisis ordinasi menggunakan MDS (Schaduw, 2015) (Gambar 1).

Selanjutnya, nilai indeks keberlanjutan integrasi sapi-sawit dikelompokan kedalam empat tingkatan, yaitu: 0,00-0,25 (tidak berkelanjutan); 25,01-50,00 (kurang keberlanjutan); 50,01-75,00 (cukup keberlanjutan); dan 75,01-100,00 (berkelanjutan).
Analisis Monte Carlo merupakan rangkaian dalam metode Rap-CP untuk menduga tingkat kesalahan acak (random error) pada model yang dihasilkan dari analisis MDS untuk semua dimensi pada tingkat kepercayaan 95\%. [Semakin kecil nilai] antara hasil analisis MDS dan analisis Monte Carlo maka semakin baik model yang dihasilkan metode Rap-CP (Suwarno et al., 2011 dan Hasrat, 2014). Nilai akhir yang dihasilkan dari analisis Rap-CP, yaitu nilai indeks keberlanjutan, koefisien determinasi $\left(\mathrm{R}^{2}\right)$ dan nilai [s-stress (S)]. Suwarno et al. (2011) menyatakan bahwa model dikategorikan goodness of fit (cukup baik) apabila memiliki nilai $\mathrm{S}<$ 0,25 dan $\mathrm{R}^{2}>80 \%$ atau mendekati $100 \%$.

Posisi keberlanjutan sistem yang dikaji akan berada di antara dua titik ekstrem tersebut (Fauzi dan Anna, 2005: Fisheries, 2002). Nilai ini merupakan nilai indeks keberlanjutan sistem integrasi sawit-sapi (Multi Dimensional Scaling). Ilustrasi hasil ordinasi yang menunjukkan nilai indeks keberlanjutan dari sistem yang dikaji disajikan pada Gambar 2 (Kavanagh dan Pitcher, 2004), metoda Rapfish-CP memiliki beberapa keunggulan yaitu sederhana, mudah, cepat, serta biaya yang murah.

Kriteria dan indikator keberlanjutan integrasi sapi sawit di Kecamatan Bahar Utara adalah: 
a. Dimensi Lingkungan.

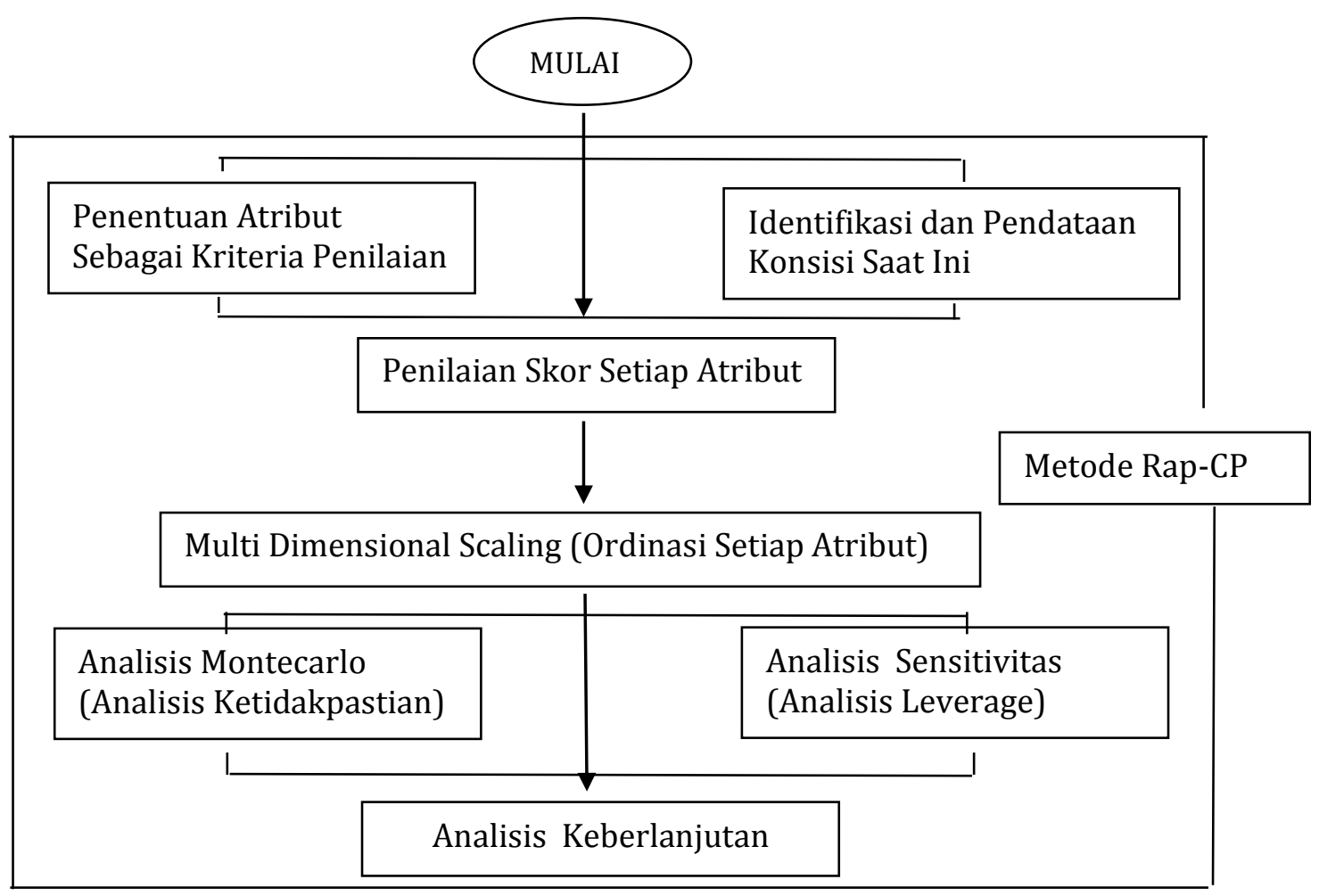

Gambar 1. Tahapan analisis data

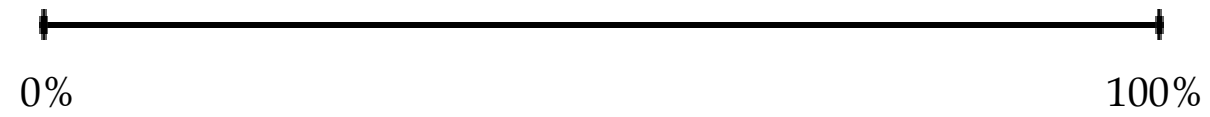

Gambar 2. Ilustrasi Indek Keberlanjutan integrasi sawit-sapi di Kecamatan Bahar Utara Kabupaten Muaro Jambi.

b. Dimensi Ekonomi

c. Dimensi Sosial Budaya

\subsection{Keadaan Umum Wilayah Penelitian}

Kabupaten Muaro Jambi dengan luas wilayah $5.264 \mathrm{~km}^{2}$ terletak di antara $1{ }^{\circ} 30^{\prime} 0^{\prime \prime}-2^{\circ} 00^{\prime} 0^{\prime \prime}$ LS dan di antara 103030'0" - 104 0'0"BT. Kecamatan Bahar Utara dengan topografi dataran, memiliki luas $\pm 15.937 \mathrm{Ha}$.

Kondisi daerah terdapat berbagai jenis hijauan pakan ternak hijauan seperti rumput Axonophus compressus, Ottochloa, panicum, Axistachia gigantea, Calopogonium, Tithonia, Melastoma malabatricum, dan lain-lain.

Berdasarkan hasil FGD, indikator keberlanjutan integrasi sapi-sawit di Kecamatan Bahar Utara ditentukan sebanyak 26 indikator; terdiri dari sembilan indikator dimensi ekologi, delapan indikator dimensi ekonomi dan sembilan indikator dimensi sosial budaya. 


\subsection{Indeks KeberlanjutanSapi Sawit Di Kecamatan Bahar Utara Dimensi Ekologi}

Dimensi ekologi merupakan cerminan dari kondisi kualitas lingkungan dan kondisi sumberdaya alam berikut prosesproses alami didalamnya baik yang dapat atau tidak dapat mendukung secara berkelanjutan dalam sektor pengelolaan sapi sawit (PASPI. 2014).

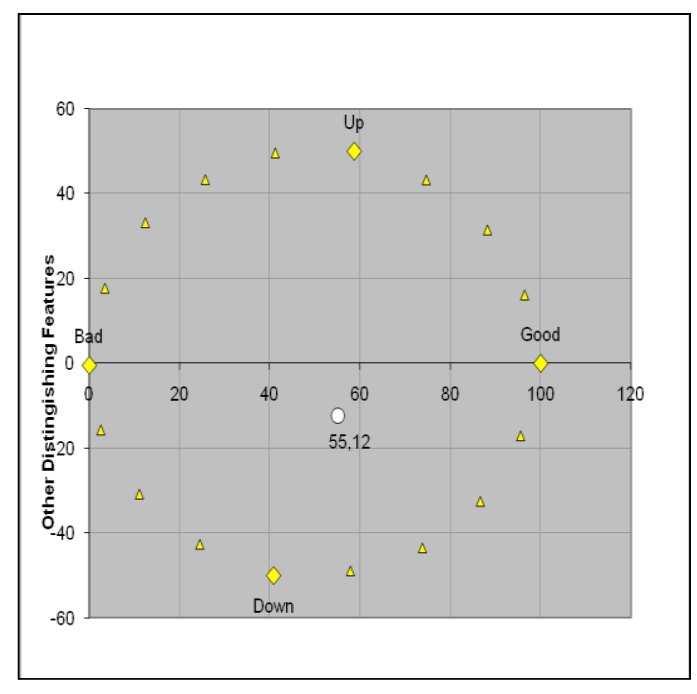

Gambar 3. Nilai Indeks Dimensi Ekologi

Hijauan pakan untuk diberikan pada ternak yang dipelihara di dalam kandang (Umar, 2009). Populasi ternak yang ada di Kecamatan Bahar Utara menentukan kepadatan populasi, pada awalnya terdapat 1.749 ekor. Hal ini menunjukkan bahwa kepadatan ternak sapi yang cukup tinggi. Tingginya populasi ternak
Berdasarkan hasil analisa multidimensional scaling (MDS) nilai dimensi ekologi adalah sebesar 55,12\% (cukup berlanjut), sebagaimana yang digambar pada Gambar 3. Selanjutnya dari hasil analisis leverage yaitu 1) Pemanfaatan hijauan pakan di bawah tanaman sawit untuk pakan ternak sapi; 2) Kepadatan ternak (ekor ternak/ 1000 orang); 3) Sistem Pemeliharaan ternak sapi. Adapun ilustrasi hasil analisis leverage sebagaimana disajikan pada Gambar 4.

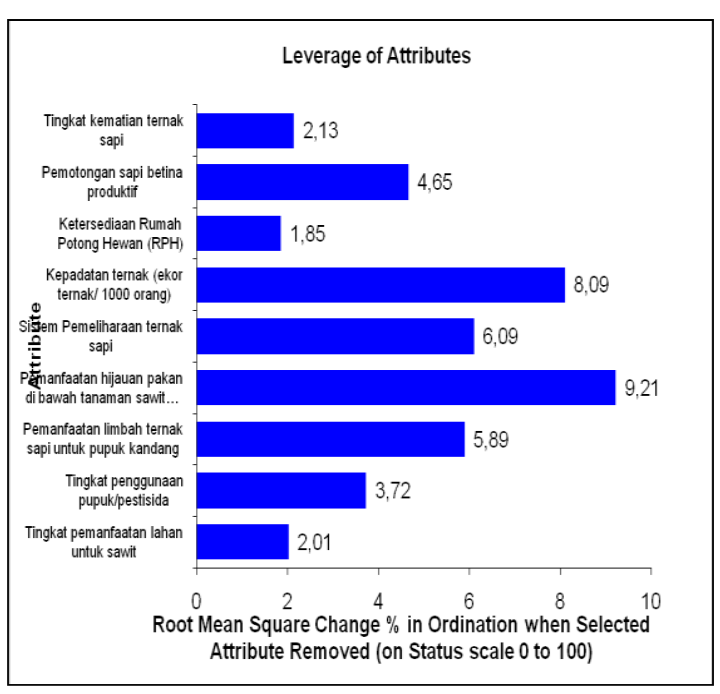

Gambar 4. Peran masing-masing Atribut Ekologi yang dinyatakan dalam Bentuk Nilai Root Mean Square.

sapi didukung oleh sistem pemeliharaan ternak sapi yang baik.

\subsection{Dimensi Ekonomi}

Nilai keberlanjutan dimensi ekonomi terhadap integrasi sapi sawit kategori bernilai 79,60\% dan ini berarti nilai indeks dimensi ekonomi berstatus berkelanjutan 
sebagaimana disajikan pada Gambar 5. Dari hasil analisis leverage ada tiga atribut yang paling sensitif: 1) Kemitraan

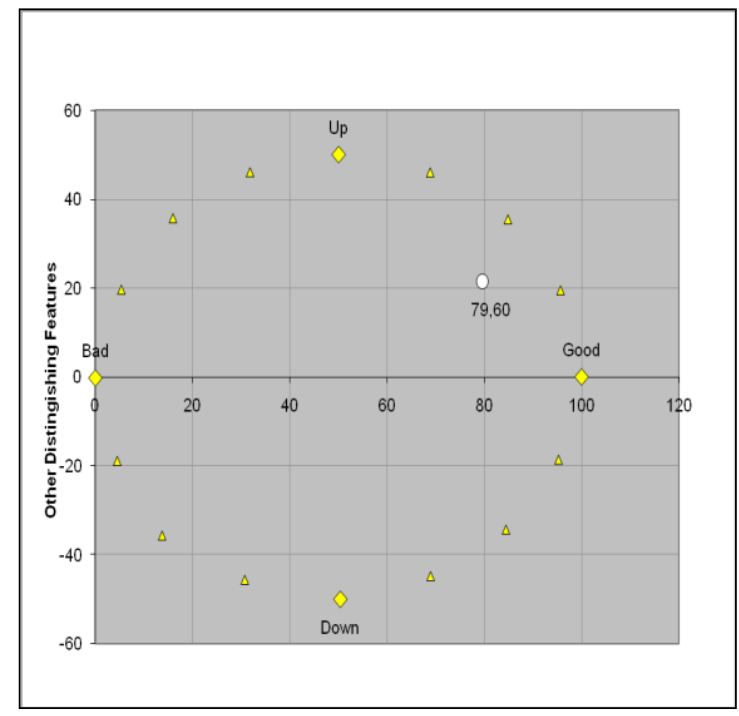

Gambar 5. Nilai Indeks Dimensi Ekonomi

Aktivitas pemeliharaan sapi sawit yang telah dilakukan petani peternak di Kecamatan Bahar Utara. Petani memiliki ternak ada yang mencapai 20 sampai 30 ekor per kepala keluarga. Pada saat populasi ternak yang tinggi dan belum banyak ternak sapi yang terserang penyakit jembrana menunjukkan taraf ekonomi penduduk yang tinggi, tetapi kegiatan ini dilakukan secara individu atau tanpa ada kemitraan dengan perusahaan kebun sawit (PTPN VI), baik dalam penyediaan bibit ternak, obat-obatan ternak, pakan konsentrat, penjualan ternak. Sehingga pada saat terjadi wabah penyakit menyebabkan perusahaan dengan peternak; 2) Besarnya subsidi; 3) Kelayakan finansial dan Ekonomi. Adapun ilustrasi pada Gambar 6.

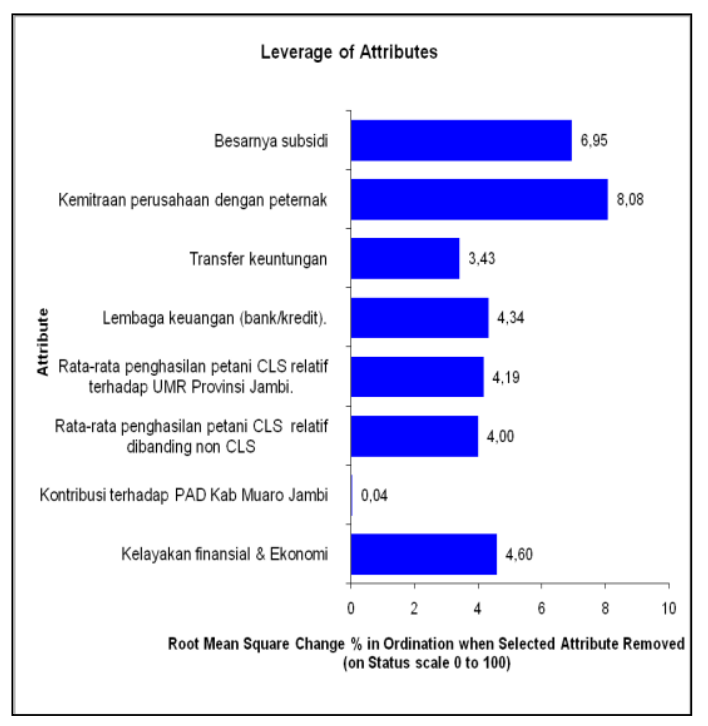

Gambar 6. Peran masing-masing Atribut Ekonomiyang dinyatakan dalam Bentuk Nilai Root Mean Square.

petani peternak mengalami kerugian yang besar. Belum adanya kemitraan antara perushaan dengan petani menyebabkan banyak petani yang merasa takut untuk memelihara sapi.

Kondisi ekonomi petani masih bergantung pada usaha utama dari perkebunan kelapa sawit, sehingga dengan menunrunnya populasi ternak yang dipelihara hanya 3-4 ekor per kepala keluarga menyebabkan tingkat ekonomi dan tabungan petani peternak menurun dan berimbas pada pendapatan asli daerah yang berasal dari ternak sapi juga menurun. 


\subsection{Dimensi Sosial Budaya}

Nilai indeks dimensi sosial budidaya pada sistem pengelolaan sapi-sawit setelah dilakukan analisis dengan MDS diperoleh nilai $52,17 \%$ sebagaimana disajikan pada Gambar 7. Nilai indeks tersebut termasuk kategori cukup

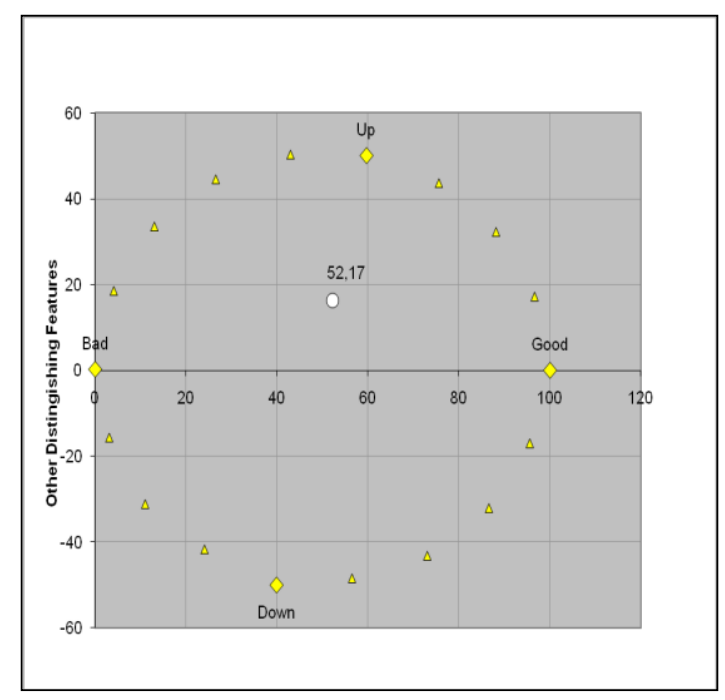

Gambar 7. Nilai Indeks Dimensi Sosial

\subsection{Multi Dimensi (Ekologi, Ekonomi dan Sosial)}

Nilai indeks multi dimensi diperoleh nilai $64,39 \quad \%$ sebagaimana disajikan pada Gambar 9. Nilai indeks tersebut termasuk kategori cukup berlanjut (skala $0 \mathrm{~s} / \mathrm{d}$ 100). Dari hasil analisis leverage diperoleh atribut yang mempunyai pengaruh paling sensitif adalah Persepsi/peran masyarakat dalam usaha tani CLS (Wahyuni et al, 2012). Adapun ilustrasi leverage disajikan pada berlanjut (skala $0 \mathrm{~s} / \mathrm{d}$ 100). Dari hasil analisis leverage diperoleh tiga atribut : 1) Persepsi/peran masyarakat dalam usaha tani CLS; 2) Frekwensi penyuluhan dan pelatihan; 3) Kelembagaan /Kelompok tani. Ilustrasi disajikan pada Gambar 8.

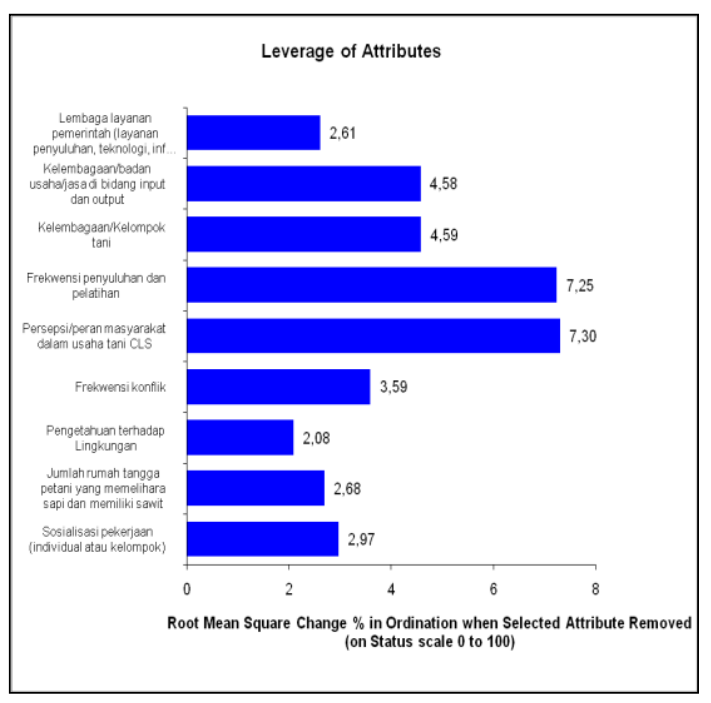

Gambar 8. Peran masing-masing Atribut Sosial yang dinyatakan dalam Bentuk Nilai Root Mean Square.

Gambar 10. Hasil ini menunjukkan bahwa strategi dalam pengelolaan sistem integrasi sapi sawit harus didukung oleh persepsi dan partisipasi petani peternak untuk keberhasilan suatu usahatani.

Kondisi sosial masyarakat yang rata-rata memiliki ternak sapi telah menunjukkan bahwa partisipasi yang tinggi untuk meningkatkan pendapatan yang dapat menunjang status sosial petani peternak. Kegiatan ini juga didukung oleh adanya tenaga 
pendamping yang memberikan penyuluhan dan pelatihan kepada petani peternak tentang manfaat dari sistem integrasi sapi sawit. Dalam mencapai keberhasilan usahatani petani peternak telah membentuk kelompok tani yang merupakan suatu kelembagaan

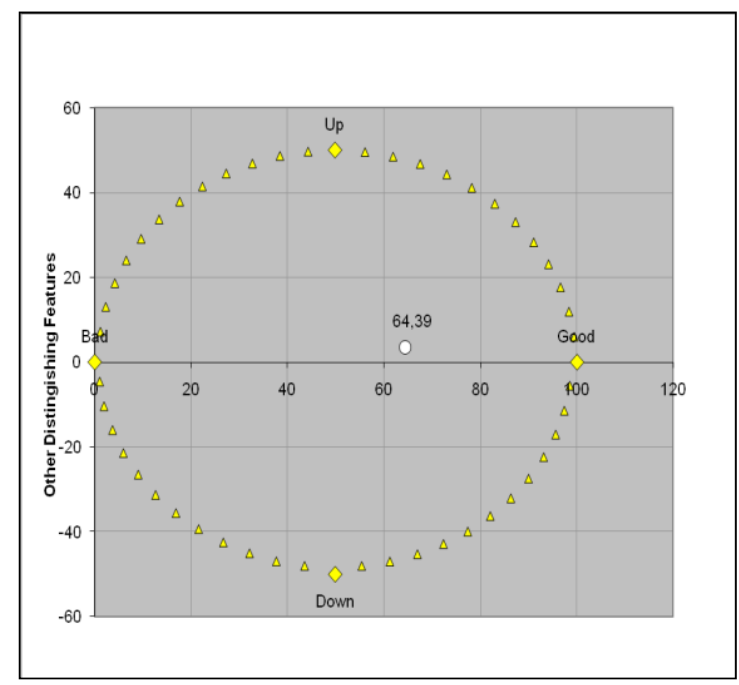

Gambar 9. Nilai Indeks Multidimensi (ekologi, Ekonomi dan Sosial)

\section{Kesimpulan Dan Saran Kesimpulan}

1. Faktor penentu keberhasilan sistem integrasi sapi sawit di Kecamatan Bahar Utara berdasarkan dimensi ekologi; Pemanfaatan hijauan pakan di bawah tanaman sawit untuk pakan ternak sapi, dimensi ekonomi; Kemitraan perusahaan dengan peternak, dan dimensi sosial; Persepsi/peran masyarakat dalam usahatani sapi sawit. yang membantu petani peternak dalam pemberdayaan petani. Dengan adanya kelembagaan akan memberikan kemudahan bagi petani untuk bersosialisasi dan mencari bantuan dalam pengembangan usahatani agar menjadi lebih baik.

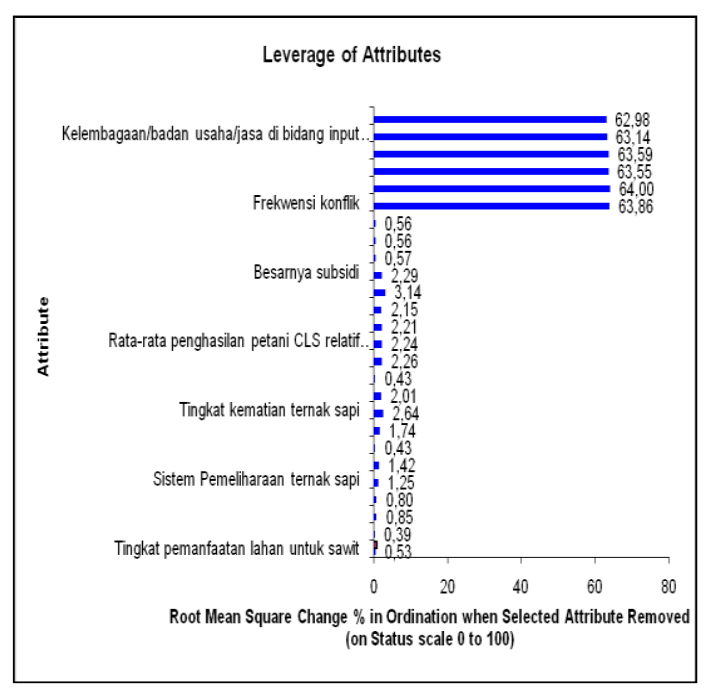

Gambar 10. Peran masing-masing Atribut Multidimensi yang dinyatakan dalam Bentuk Nilai Root Mean Square.

2. Strategi kebijakan integrasi sapi sawit kedepan dengan mendorong dimensi ekologi dan dimensi sosial masyarakat, seperti pemanfaatan lahan sebagai sumber hijauan pakan dan meningkatkan persepsi serta partisipasi petani peternak dengan membangun pola kemitraan pada perusahaan seperti perusahaan perkebunan sawit PTPN VI. 
Saran.

Perlu dilakukan sosialisasi dan pendampingan secara kontinu kepada petani peternak untuk menjaga kesehatan ternak dan lebih hati-hati dalam mendatangkan ternak ke Kecamatan Bahar Utara serta selektif dalam memilih ternak sapi.

\section{Ucapan Terima Kasih}

Terima kasih kepada Direktorat Pendidikan Tinggi Kemenristek Dikti, Rektor Universitas Jambi dan Ketua Lembaga Penelitian dan Pengabdian pada Masyarakat Universitas Jambi yang telah memberikan bantuan dana sehingga penelitian ini dapat dilaksanakan.

\section{Daftar Pustaka}

Alder, J., Pitcher, T.J., Preikshot, D., Kaschner, K., and Feriss, B. 2000. How good is good? A rapid appraisal technique for evaluation of the sustainability status of fisheries of the North Atlantic. Sea Around Us Methodology Review. Vancouver, Canada: Fisheries Centre, University of British Columbia.

BPS Muaro Jambi. 2017. Kecamatan Bahar Utara Dalam Angka 2017. ISBN: 978-602-6538-086.

Cisse, A.A., Blanchard, F., and Guyader, O. 2014. Sustainability of tropical small-scale fisheries: Integrated assessment in French Guiana. Marine Policy, 44, 397-405.

Diwyanto, K., D. Sitompul, I. Manti, I.W. Mathius, dan Soentoro. 2004. Pengkajian pengembangan usaha sistem integrasi kelapa sawit-sapi. Dalam Prosiding Lo-kakarya Nasional Sistem Integrasi Kelapa Sawit-Sapi. Bengkulu, 9-10 September 2003. Badan Penelitian dan Pengembangan Pertanian, Pemerintah Provinsi Bengkulu dan PT Agricinal, Bogor.

Fauzi, A. dan S. Anna, 2005. Pemodelan Sumber Daya Perikanan dan Lautan untuk Analisis Kebijakan. Gramedia Pustaka Utama. Jakarta.

Fisheries Centre, 2002. Attributes of Rapfish Analysis for Ecological, Technological, Economic, Social and Ethical Evaluation Fields. Institute of Social and Economic Research Press. St John's Canada.

Hasrat, A.S. 2014. Status keberlanjutan pengelolaan perikanan budi daya di pulau-pulau kecil Makasar. Jurnal Manajemen Perikanan dan Kelautan, 1 (1). 
Husnain dan N Dedi.2015.

Peranan Bahan Organik dalam Sistem Integrasi Sawit-Sapi. Jurnal Sumberdaya Lahan Vol. 9 No. 1, Juli 2015; 27-36.

Kabupaten Muaro Jambi Dalam Angka. 2017. Muaro Jambi Dalam Angka .BPS Kabupaten Muaro Jambi. ISBN: 978-602-6538-03-1.

Kavanagh, P. 2001. RAPFISH Software description (for Microsoft Excel) project. Vancouver: Fisheries Centre University of British Columbia.

Kavanagh, P. and T. J. Pitcher, $2004 . \quad$ Implementing Microsoft Excel Software for Rapfish : A Technique for The Rapid Appraisal of Fisheries Status. University of British Columbia. Fisheries Centre Research Reports 12(2).

Marimin, 2002. Teknik dan Aplikasi: Pengambilan Keputusan Kriteria Majemuk. Jakarta: Grasindo.

PASPI. 2014. The Sustainability of Indonesian Palm Oil Industry. First Edition. Bogor. $128 \mathrm{hlm}$.

Permentan RI No 105 tahun 2014 Tentang Integrasi Usaha Perkebunan Kelapa Sawit Dengan Usaha Budi Daya Sapi Potong

Pitcher, T. J. and D. Preikshot. 2001. Rapfish: A Rapid Appraisal Technique to Evaluate The Sustainability Status of Fisheries. Fisheries Research 49 (2001) : 255-270.

Schaduw, J.N.2015. Keberlanjutan pengelolaan ekosistem mangrove Pulau Mantehage, kecamatan Wori, Kabupaten Minahasa Utara Provinsi Sulawesi Utara. Jurnal LPPM Bidang Sains dan Teknologi, 2 (2), 60-70.

Suwarno, J., Kartodihardjo, H., dan Pramudya, B. 2011. Pengembangan kebijakan pengelolaan berkelanjutan DAS Ciliwung Hulu Kabupaten Bogor, Jurnal Analisis Kebijakan Kehutanan. 8 (2), 115-131.

Syarifuddin, H. 2010. Integrasi Ternak Sapi dengan Tanaman Kelapa Sawit Berbasis Indeks Keberlanjutan Studi Kasus Di Sungai Bahar. Jurnal Penelitian Universitas Jambi Seri Sains. Vol XII. No 4, Edisi September 2010. ISSN:0852-8349. Hal 29-35.

Umar, S. 2009. Potensi Perkebunan Kelapa Sawit Sebagai Pusat Pengembangan Sapi Potong dalam Merevitalisasi dan Mengakselerasi Pembangunan Peternakan Berkelanjutan. Pidato Pengukuhan Jabatan Guru 
Besar Tetap dalam Bidang Ilmu Reproduksi Ternak. Universitas Sumatera Utara, Medan.

Wahyuni, S., E.S. Harsanti, dan D. Nursyamsi. 2012. Sistem Integrasi Tanaman Ternak
(SITT) di Lahan Sawah Tadah Hujan untuk Antisipasi Perubahan Iklim. Sinar Tani. Agroinovasi. Edisi 4-10 April No. 3451 Tahun XLII. Badan Litbang Pertanian. 